\title{
Evaluation of some plant extracts in vitro against Colletotrichum capsici causing fruit rot of Bhut jalakia (Capsicum chinense) in Assam
}

M.K. KALITA*, D. BORA AND P.P. NEOG ${ }^{1}$

Department of Plant Pathology, B.N. College of Agriculture (A.A.U.), BISWANATH CHARIALI (ASSAM) INDIA

${ }^{1}$ Department of Nematology, B.N. College of Agriculture (A.A.U.), BISWANATH CHARIALI (ASSAM) INDIA

\section{ARITCLE INFO}

$\begin{array}{ll}\text { Received } & : 02.07 .2014 \\ \text { Accepted } & : 29.09 .2014\end{array}$

\section{KEY WORDS :}

Evaluation, Plant extract,

Colletotrichum capsici, Capsicum

Chinense

*Corresponding author:

Email:raghu_iari@yahoo.com
How to view point the article : Kalita, M.K., Borah, D. and Neog, P.P. (2014). Evaluation of some plant extracts in vitro against Colletotrichum capsici causing fruit rot of Bhut jalakia (Capsicum chinense) in Assam. Internat. J. Plant Protec., 7(2) : 492-493. 